\title{
European Union as a Leader in Climate Change Policy: Assessing Europe's Roles in the World ${ }^{*}$
}

\author{
Omer Ugur, Lecturer, MA \\ Kadir Caner Dogan, Assist. of Prof. \\ Metin Aksoy, Assist. of Prof. \\ Gumushane University, Turkey
}

doi: 10.19044/esj.2016.v12n5p285 URL:http://dx.doi.org/10.19044/esj.2016.v12n5p285

\begin{abstract}
The European Union has grown up in terms of influence and size in international politics. The size of its economy and the ever-increasing membership, have seen its ambitions grow meaning that the EU now has an international presence it did not have at its formation. It is easy to say that with the EU being an ambitious actor in international politics, the rise into prominence of climate change naturally came in handy for the EU as it provided an opportunity for the EU to assert itself and prove both its capacity and presence. The 1992 Rio Earth Summit and the withdrawal of the USA from the obligations of the Kyoto came as a blessing in disguise for the Union as it seized the moment to assert itself. Thus, in trying to understand what role the EU has or is playing in international climate change politics, there is need to assess its leadership claims and what it has done to prove these claims. To get there, the paper will navigate through a part of the discipline of International Relations (IR) to understand how it provides for a basis to explain or understand the EU's limitations and strengths on actorness.
\end{abstract}

Keywords: The European Union, Climate Change, Actorness, Leadership.

\section{Introduction}

As with many other issues -dealing with economic crises, combating global terrorism and controlling the proliferation of nuclear and mass destruction weapons- climate change is commonly regarded as one of the most urgent and pressing issues of our time to be found high on the political agenda at all levels-locally, nationally, internationally, and of course at the

\footnotetext{
* This study which was presented in International Conference on Education, Psychology, and Social Sciences (ICEPS-2015) in Taipei/Taiwan is revised and expanded.
} 
level of the European Union (EU). Recognising climate change as a global problem and need to take the issue seriously, the international community, thus, has been actively interested in the impact and causes of this phenomenon at global level since the 1970's. Moreover, in order to deal with this threat, an international climate change regime under United Nations (UN) was established after rounds of international negotiations (Gupta \& Grubb, 2000, p.16). As a naturel consequence of these developments, the governments have found themselves under intense pressure to deliver policy solution to deal with climate change since that period. In this context, the EU set out its ambitions as early as 1988 announcing that it should, itself, take the lead in climate action. As a result, the EU's attention, over the last decade, has been primarily focused on developing a coherent plan to infuse climate change into its international commitments leading to the EU being characterised as a leader in international climate change policy (Bretherton \& Volger, 2006; Oberthuur, 2007).

It is easy to say that with the EU being an ambitious actor in international politics, the rise into prominence of climate change naturally came in handy for the EU as it provided an opportunity for the EU to assert itself and prove both its capacity and presence (Bretherton \& Vogler, 2006). However, while the European Union has been actively and progressively engaging itself in tackling climate change, the EU has largely failed in exporting its policy solutions to the international level, as Copenhagen conference demonstrates in 2009. The fact that no legally binding agreement was reached to succeed the Kyoto Protocol and the Copenhagen Accord itself is hardly reflective of the EU ambitions reflects negatively on the EU capabilities on the tasks it has set for itself. Because of that, this leads to the old questions again: is the EU really an actor in international politics? Is it capable, and does it possess the capacity to deliver what the commission espouses? How does an organisation like the EU become an actor in the context of International Relations when it is not state? Thus, the paper shall seek to underpin the theoretical attempts to integrate new actors into the discipline of IR and how that sheds light into the potentials, the possibilities, successes and failures of the EU's actorness and how they have enhanced their involvement on the climate regime. Finally and more crucially, this will feed into the Climate Change which is at the core of the enquiry and analysis. How has EU involvement in climate politics enhanced its actorness on global politics and development?

\section{Understanding EU's Actorness}

Traditionally, actorness has largely been judged by the states' involvement in 'high politics' (Bretherton \& Vogler, 2006, p.3) which refers to security and foreign policies. In other words, the ability to use force and 
the impact on other actors in the world politics is the determinant of greatpower status. According to the classical and realist approach, only states are actors and other organisations or transnational enterprises are simply acknowledged or given certain status commensurate with their relevance then but they still remain understood to be below the states in terms of international status. In this sense, 'realism,' write Bretherton and Vogler, 'provides an essentially political analysis in which power differentials between states area central focus. Ultimately, the actors of interest to Realists are powerful states’ (Bretherton \& Vogler, 2006, p.19).

Therefore, issues such as environment, or climate politics are considered peripheral as they don't readily make for 'high politics' and in this case what makes this interesting is the fact that the EU's beginnings itself saw these issues also peripheral with the Commission interested in the economic issues more. The limited scope of the EU's origins -that is the quest for economic revival and stability in the aftermath of the Second World- can serve as the basis to explain the EU's actorness on international change politics today. As we can see, the initial agenda of the EU was limited meaning that the EU naturally became largely civilian concerned with economic revival and less with other issues such as foreign and security policy. Despite the fact that the EU did make attempts at environmental policy through the Single Market Act of 1987 and the treaties of Maastricht (1992) and Amsterdam (1997) and finally Lisbon (2009); and also made headway in some specific issues such as acid rain through the Large Combustion Plants Directive, issues of the environment and climate change were not so much of an issue in the EU agenda until 1990s (Oberthuur, 2007).

From this approach to International Relations the EU's potential to grow into a political giant in international affairs was naturally doomed to be overlooked. And yet over the years these issues, particularly climate change, have become relevant and this has been confirmed by the publicity and attendance enjoyed by the Copenhagen conference in 2009. Indeed, Bretherton and Vogler (2006) believe that once we accept the significance of climate change as a key arena of contemporary international relations, perhaps even achieving the status of high politics, we are forced to consider the EU itself as an actor.

And yet the EU's status is not without problems. The 'EU', says Ginsberg (1999), 'is neither a state nor a non-state actor, and neither a conventional international organisation nor an international regime' (Ginsberg, 1999, p.432). For that reason alone it is difficult to define it as a great power in the real sense of the phrase and yet the EU is present and influential in international politics particularly in issues to do with the economic development, humanitarian aid and assistance and environment 
where it plays a significant role in policy shaping and delivery and international negotiations (Bretherton \& Vogler, 2006; Zito, 2005). Therefore, it can be seen that the EU as one of the newer participants in global politics and a rather different type of an actor in IR poses some difficulties for analysis of its actorness as it sometimes acts as a state, but fundamentally it is not a state (Jupille \& Caporaso, 1998). In essence, the EU languishes in the grey area between a state and an international organisation something which triggers up all manner complexities in trying to theorise on the EU's actorness on the international stage. And yet still it has over the years asserted itself progressively in a way that its actorness has attracted a huge body of comment.

Despite the fact that in traditional international relations terms only states with right to sign treaties with other states qualify as actors in the world system (Bull, 1982; Mearsheimer, 2007), scholarship has evolved with the spread of the EU influence to pay attention to this phenomenon which renders the EU as a special kind of an actor. As has been said, this complex nature of the EU manifests itself more vividly in the sense that it is some kind of an emerging state with features of a state while at the same time it remains an international organisation bringing together fragmented activity with itself acting as the convener and an overseer (Elgstrom \& Smith, 2006). Bretherton and Vogler (1999) have also treated the EU as an actor in its own right with a legal status in the international system. As the EU's impact on the international stage has tended to deepen over the years terms like 'actorness' and 'presence' have equally evolved to assume broader or dynamic meanings and since the 1970's scholarship has played its part in all this development. Scholarship varies as to the explanation of developments such as a pattern alluded to above. In trying to explain these complexities, one cannot fail to think of Bretherton and Volger (2006), Jupille and Caporaso (1998) whose analysis shed more light as opposed to confusing and concealing. Their views just as does those of Hill (1993) will help not only to understand the dynamics and complexities of EU actorness but to test the fact that the EU is indeed active in international climate politics but there is something lacking in terms of its capacity to lead.

While these are complementary, as has been said earlier, one cannot fail to see how Bretherton \& Vogler (2006) further resonates with Hill's thesis of credibility expectations gap which is mainly about what one might call the EU's inherent problem-the 'painful contrast between what publics or outsiders might think the EU could/should do, and what it actually could deliver' (Hill, 1993, p.3). It will be worthwhile to look into these scholars' assertions so as to gain an in-depth understanding of the complexities attendant to the EU policy. Clearly, the EU's participation means that while it is not a state, the EU is a 'presence' with recognisable influence and the 
patterns of behaviour means that the EU cannot be ignored by the states and other international organisations (Ginsberg, 1999). Over the years, and despite the varying interpretations, scholarship is almost united in the view that the EU's participation on the international politics can no longer be contested and neither can the EU's actor status be diminished. And yet problems still persist.

\section{EU Leadership in Climate Change and the Development of the Global Climate Change Regime}

Once we have accepted that the EU is an actor of note in international politics, we almost certainly cannot avoid enquiring what its role has been or is in one of the most pressing issues of our time-climate change. First, the rise of climate change in the international development radar has seen many EU countries and the EU itself seeking to shape the global climate regime. Secondly, the EU itself considers itself a leader in global climate policy and that view is universally recognised by leading climate practitioners and is shared amongst the media and the scientists. The failure or refusal of the US to commit to the global environmental regimes in the 1990's and the combination of unwillingness and inability of other nations such as China, Russia and Japan amongst many to take the lead came in handy for the EU. Already harbouring leadership the EU seized the moment and did not just throw its weight about trying to shape the global climate regime but literally declared itself as a leader.

Therefore, in trying to understand what role the EU has or is playing in global climate change politics, there is need to assess its leadership claims and what it has done to prove these claims. Scholarship seems consistent in the assertion that leadership is of crucial importance in the multilateral organisations (Gupta \& Ringius, 2001; Sannerstedt, 2005). These scholars emphasize on the importance of leadership in order that agreements may be reached and so does Sannerstedt (2005) who believes that leadership is a key to forestalling deadlocks and to 'ease the negotiations' way to sound solutions. With clear leadership, problems attendant to multilateral negotiations are better dealt with (Nabers, 2008).

Leadership, says Underdal, (1994) refers to 'an asymmetrical relationship of influence, where one actor guides or directs the behaviour of others towards a certain goal over a certain period of time' (Underdal, 1994, p.178). It is a 'relationship between a leader and followers' (ibid. p. 181). Fundamental to this relationship are the ways in which the leaders supply the demands and share the responses of the followers. Nabers (2008) proffers yet another interesting observation about the dynamics of leadership. 'Leadership', he argues, 'is always contested by challenges from those who are left out of what we will call a 'hegemonic project', and sometimes from 
those who find themselves in a subordinate position to the leader' (Nabers, 2008, p.9).

While there is no disputing that these scholars including a range of scholars, for example, Oberthuur and Kelly (2008), Bretherton and Vogler (2006), Zito (2005), have zealously dwelt on the EU's engagements around the Kyoto Protocol, Oran R. Young (1991) is probably one of the more significant in this context of multilateral negotiations. Young (1991) is best known for his theory of three forms of leadership: structural, entrepreneurial, and intellectual leadership all of whom have been seen to be influenced by a neo-realist approach to international relations. Young is countered by Alexandra Lindenthal (2009) who argues that the principles of neo-realism hardly conform to the nature of the nations' relationships with regards climate change. Based on the constructivist outlook Lindenthal (2009), as cited in Kellerhaus (2010) proposes her own types of leadership: selfserving, Norm-establishing, problem-solving and mediating. She also identifies leadership indicators as interests, resources, power, norms and communication meaning that the rate, extent and manner in which a leader exhibits or exercises these indicators will indicate what type of a leader they are and will also determine their success on a particular area of action. For example, to achieve particular interests a self serving leader may go an extra mile by over relying on their material resources to control other actors.

At face value these forms of leadership may seem separate and yet at practice and reality level they appear not to be mutually exclusive per se. The manner in which the EU has conducted itself with regards the global environmental politics may help to illustrate this. Between 1990 and 2007, Lindenthal (2009), as cited in Kellerhaus (2010), argues, the EU has practiced all these forms of leadership. For example, the EU has never hidden its intentions to export its norms to other regions and nations and the case of the environmental protection proves this because the protection of the environment is an indisputable EU value. The EU has also played a mediating role on many occasions, solved problems and in this case it is indeed determined to solve the problem of climate change. Just as it is in the interests of the smaller nations to have climate change tackled it is also in the $\mathrm{EU}$ interests to do so and therefore the EU is to a certain small degree a selfinterested leader.

\section{EU Contribution towards the Shaping of Global Climate Change Regime}

Meanwhile as the leadership debate has been growing the EU has been actively involved on the environmental front in a way that has seen it shape the regime to some considerable degree. Opposed to the Kyoto Protocol and to a range of other multilateral packages such as the Convention 
on Biodiversity the US's withdrawal unwittingly paved the way for the ambitious EU to make a contribution towards the development of the global environmental governance. It can be argued that the Kyoto Protocol owes its existence to the EU more than to any state.

Interestingly few if any foresaw the emergence of the EU as leader in global environmental governance. This may perhaps be because until the 1987 Single European Act the EU had no common environmental policy and there was no formal treaty recognising the importance of the protection of the environment. And yet there was evidence that the EU was establishing itself through out that period as a standard bearer by achieving competences in areas such as the air pollution, water quality and waste disposal. The EU economy grew in a way that naturally prompted action on the environmental front. By 2014, for example, the EU, with only 28 member states, have become the second largest oil consumer in the world after the US. With the EU mandarins harbouring ambitions to steer the EU towards leadership on the global stage this growth and development came in handy (Oberthuur, 2007). Prior to this it was the USA which was a global leader and yet by the early 1990's it was clear that opportunities were arising for the EU to surge ahead and achieve her ambitions.

The EU leadership on the environmental issues has not been an isolated case, though. Academic enquiry has naturally spread to other policy areas such as the multilateral trade negotiations (Smith \& Woolcock, 1999), international development policy (Orbie, 2007), and to international law where the EU has been seen to be active in the International Criminal Court (Groenleer \& van Schaik, 2005) and the nuclear non-proliferation regime (Muller, 2010). In this context, the EU's contribution towards the development of a global climate change regime remains a major interest for many academics. There has been a proliferation of observations from the outsiders on the implications or perceptions of the EU's role and leadership in negotiations (Killian \& Elgstrom, 2010). Out of this analysis on the EU leadership in international politics a readable pattern has emerged. Commentary has tended to reflect an academic obsession with the EU's inherent constrains; and strengths and potential. To be precise the emphasis of a range of scholars particularly Grub and Gupta (2000), Zito (2005), Bretherton and Vogler (2006), has been on competence, capability, consistence and coherence. Perhaps this has been made possible by the fact that while there has been no doubt that the $\mathrm{EU}$ is a formidable actor in global environmental regime its performance has been variable and contradictory.

While the EU has demonstrated high competence, decisiveness and exemplariness in such policy areas as trade in toxic waste, the EU has previously seen to be both divided and obstructive. The Montreal Protocol negotiations of the late 1980's will prove this (Vogler, 2005, p.840). 
Inconsistencies are readable in other areas. With regards climate change the situation is even more interesting. Despite having shown backbone and drive in the greenhouse gas reduction ahead of the Kyoto provisions, the EU is seen as having failed to exercise enough flexibility to adequately respond to the US's proposals and was also seen to have been in disarray in New Delhi in 2002 (Vogler, 2005, p.840).

Over the last decade, the EU's leadership assessments have been more encouraging (Keleman \& Vogel, 2009; Groenleer \& Van Shaik, 2005). Emphasis has tended to change with the scholars drifting towards the possibilities of the EU leadership and how it could lead-turning its potential into action. They have emphasised on the EU's 'enhanced', 'strengthened' and 'improved' leadership record (Keleman \& Vogler, 2009; Oberthur \& Kelly, 2008). To emerge from this positive development has been an acknowledgement of the EU's progress in practical terms. For example, the EU's actorness in the case of the Kyoto Protocol and the United Nations Framework Convention on Climate Change (UNFCCC) and its actions in its own affairs particularly with regards to its ability to successfully set the highest $\mathrm{CO} 2$ reductions targets for itself and its being active in pushing for higher international targets have boosted the EU's leadership credentials. The EU is, it is said, a 'directional leader'-that is one leading by example setting the standards (Parker \& Karlsson, 2010; Falkner, 2007). There has also been recognition of the EU's potential. The EU, it is argued, has great potential to become a structural leader-that is through a carefully worked out mixture of persuasion and 'carrot and stick' tactics. For the latter, the EU's economic mighty could come in handy as it could be relied on to force the third countries to bend to the EU's objectives (Vogler \& Hannes, 2007). International trade negotiations are one area where the EU could, perhaps, best exercise this type of leadership. Moreover, the EU's success in securing the ratification of the Kyoto Protocol by exerting leverage over Russia is often cited as an example (Vogler \& Hannes, 2007; Damro, 2006).

Finally, the EU's leadership has also been observed from another angle: the international stage where it has come to be seen as an international 'agenda-setter' (Zito, 2005). This is a reference to the EU's abilities in projecting some of its objectives onto the global stage coupled with a promotion of norms and values in trying to influence the negotiations and processes. For instance, while the EU did not fully reflect her agenda-setter features in 2009 Copenhagen Climate Change Summit as shown in Kyoto, it has succeeded in taking a lead to other countries in Paris Climate Change Conference as an indicators of agenda setter and directional leader. Indeed, they didn't reach to any agreement in Copenhagen Conference in order to replace Kyoto Protocol, but Paris conference shows that the EU was able to convince to other participant to take an action against climate change. Of 
course, such an outcome is related to ensuring uniformity failed in Copenhagen in 2009. In this context, as long as EU member states speak with single voice in the international arena, they are able to strengthen its actorness in the international politics and able to continue to take a leader in climate change policy.

\section{Conclusion}

It is clear that with the EU being an ambitious actor in world politics, the rise into prominence of climate change naturally came in handy for the EU as it provided an opportunity for the EU to assert itself and prove both its capacity and presence (Bretherton \& Vogler, 2006). Indeed, although the EU is a relatively new actor on the international stage, it has, in a short time, evolved its position as a dominant world actor and this remarkable revolution is evident in the activities around climate negotiations. However, the real question to be answered is whether or not the EU was effective enough? This sad reality on the part of the EU further throws light into one fundamental point: the EU's inherent dilemma is that its strengths generally tend to be the source of its weaknesses. For example, the set goal and driving force behind the EU's negotiation mandate stemmed from the EU's strengths. First, the $\mathrm{EU}$ is a major economic block encompassing some of the major national economies of the world which as has been said earlier partly informed the leadership ambitions (Oberthuur, 2009; Bretherton \& Vogler, 2006; Egenhofer \& Georgiev, 2009). A second but circumstantial strength enjoyed by the EU prior to the conference was that the EU had for years enjoyed some degree of influence since the US's refusal to commit the obligations of Kyoto in 1997 meaning that the Union had a chance to perpetuate this dominance. The EU's leadership potential was largely seen to have increased since Kyoto because since the withdrawal of the US, the EU increased its internal cooperation and evolved into a more unified and stronger entity. Thirdly the EU had an advantage in that it had set an example by setting targets for itself meaning that it had a chance to be taken seriously. And yet the combination of these strengths became the source of problems and consequently failure.

Because the 'EU', says Ginsberg (1999), 'is neither a state nor a nonstate actor, and neither a conventional international organisation nor an international regime' (Ginsberg, 1999, p.432). the sheer size, influence and economic power of the EU which partly led to its international ambitions does not always translate into a capacity to come up with realistic targets nor flexibility to be able to react to the unforeseen diktats of climate change negotiation process. Despite the fact that the EU does not achieve the success of showing its capacity through the climate change conference, the EU is a legal entity recognised by the UNFCCC to participate in such events as a 
Regional Economic Integration Organisation (REIO) - a provision instituted in recognition of the EU and other like entities' competences in specific environmental policy areas which are vital in the UNFCCC. Technically and in reality, the EU is a member of the UNFCCC and its representation at United Nation Climate Change Conference such as Kyoto or Copenhagen attests to that. In this context, the EU is not eligible to vote separately in the UNFCCC. In addition to that, it is only on issues of exclusive EU competence that the EU is eligible to vote with the number of votes equalling that of its member states. Instead, both the EU and Member States decide on their priorities and obligations together because it is not permissible for them to vote concurrently (UNFCCC, 1992, Article 22.2.). Moreover, this provision becomes a nullity for the EU in the event that any of the Members States exercise the right to vote (UNFCCC, 1992, Article 18).

Despite the fact that in traditional international relations terms only states with right to sign treaties with other states qualify as actors in the world system (Bull, 1982; Mearsheimer, 2007), scholarship has evolved with the spread of the EU influence to pay attention to this phenomenon which renders the EU as a special kind of an actor. This section seeks to examine the EU's actorness on the international system through a body of literature advanced by the many scholars who have sought to explain this complex nature and uniqueness of the EU. As has been said, this complex nature of the EU manifests itself more vividly in the sense that it is some kind of an emerging state with features of a state while at the same time it remains an international organisation bringing together fragmented activity with itself acting as the convener and an overseer. Over the years, and despite the varying interpretations, scholarship is almost united in the view that the EU's participation on the international politics can no longer be contested and neither can the EU's actor status be diminished. And yet problems still persist.

\section{References:}

Bretherton, C. \& Vogler, J. (2006). Conceptualizing Actors and Actorness, C. Bretherton and J. Vogler (Ed.), The European Union as Global Actor, London: Routledge.

Bull, H., (1982). Civilian Power Europe: A Contradiction in Terms?, Journal of Common Market Studies, 21, September/December, pp. 149-170.

Damro, C., (2006). EU-UN Environmental Relations: Shared Competence and Effective Multilateralism, Laatikainen, K. and Smith, K. E. (Ed.), The European Union at the United Nations, Hampshire: Palgrave Macmillan. Elgström, O. \& Smith, M., (2006). The European Union's Roles in International Politics: Concepts and Analysis, London: Routledge.

Falkner, R. (2007). The political economy of normative power Europe: EU 
environmental leadership in international biotechnology regulation, Journal of European Public Policy, 14(4), pp. 507-523.

Ginsberg, R. H. (1999). Conceptualizing the European Union as an International Actor?, Journal of Common Market Studies, 37(3), pp. 429454.

Groenleer, M. \& van Schaik, L., (2005). The EU as an 'Intergovernmental' Actor in Foreign Affairs: Case Studies of the International Criminal Court and the Kyoto Protocol, Centre for European Policy Studies Working Document, 228, August.

Gupta, J. \& Ringius, L. (2001). The EU's Climate Leadership: Reconciling Ambition and Reality, International Environmental Agreements, 1, pp. 281299.

Gupta, J., \& Grubb, M., (2000). Climate Change and European Leadership: A Sustainable Role for Europe, Kluwer, Dordrecht.

Hill, C., (1993). The Capability-Expectation Gap, or Conceptualizing Europe's International Role, Journal of Common Market Studies, 31(3), pp. 305-328.

Jupille, J. \& J. A. Caporaso (1998). States, Agency and Rules: the European Union in Global Environmental Politics, C. Rhodes (Ed.), The European Union in the World Community, Boulder: Lynne Rienner.

Keleman, R. D \& Vogel, D., (2009). Trading Places: The Role of the United States and the European Union in International Environmental Politics, Comparative Political Studies, 43(4), pp. 427-456.

Kellerhaus, F., (2010). The Role of the European Union at the United Nations Climate Change Conference in Copenhagen, Available at :< http://essay.utwente.nl/60336/1/BSc_F_Kellerhaus.pdf $>$ [Accessed 15 June 2015].

Kilian, B. \& Elgström, O., (2010). Still a Green Leader? The European Union's Role in International Climate Negotiations, Accepted for Publication in Cooperation and Conflict, No. 3, Available at: $<$ http:/cac.sagepub.com/content/45/3/255.abstract $>$ [Accessed 13 June 2015].

Mearsheimer, J. J., (2007). Structural Realism, M. Kurki and S. Smith, (ed.), International Relations Theories: Discipline and Diversity, OUP, Oxford: T. Dunne.

Muller, B., (2010). Copenhagen 2009: Failure or final wake-up call for our leaders?, Oxford Institute for Energy Studies, Oxford, 2010 February.

Nabers, D., (2008). Leadership and Discursive Hegemony in International Politics, Paper Prepared for the 1st Regional Powers Network Conference, Hamburg, September 15-16.

Oberthuur, S., (2007). The European Union in International Climate Policy: The Prospect for Leadership, Intereconomics - Review of European 
Economic Policy, 42(2), pp. 77-83.

Oberthuur, S., \& Kelly, R., (2008). EU Leadership in International Climate Policy: Achievements and Challenges, International Spectator, 43(3), pp. 3550 .

Oberthuur, S., (2009). The Performance of the EU in International Institutions: Negotiating on Climate Change, Paper Presented at International Studies Association Annual Convention, New York, February 15-18.

Parker, C. and Karlsson, C. (2010). Climate Change and the European Union's Leadership Moment: An Inconvenient Truth?, Journal of Common Market Studies, 48(4), pp. 923-943.

Sannerstedt, A., (2005). Negotiations in European Union Committees, O. Elgström and C. Jönsson (Ed.), European Union Negotiations: Processes, Networks and Institutions, London: Routledge.

Smith, M. \& Woolcock, S., (1999). European Commercial Policy: A Leadership Role in the new Millennium?, European Foreign Affairs Review, 4(4), pp. 439-62.

Underdal, A. (1994). Leadership Theory: Rediscovering the Arts of Management, I. W. Zartman (Ed.), International multilateral negotiation: Approaches to the management of complexity, San Francisco: Jossey-Bass Publishers.

United Nations, (1992), United Nations Framework Convention on Climate Change.FCCC/INFORMAL/84, Available at $<$ http://newsroom.unfccc.int/>, [Accessed 11 June 2015].

Vogler, J. \& Hannes, S.R., (2007). The European Union in Global Environmental Governance: Leadership in the making?, International Environmental Agreements: Politics, Law and Economics, 7(4), pp. 389-415. Vogler, J., (2005). The European Contribution to Global Environmental Governance', International Affairs, 81(4), pp. 835-850.

Young, O. R. (1991). International Governance. Protecting the Environment in a Stateless Society, , New York: Cornell University Press.

Zito, A. R. (2005). The European Union as an Environmental Leader in a Global Environment, Globalizations, 2(3), pp. 363-375. 